\title{
Effects of Exposure to Genistein during Pubertal Development on the Reproductive System of Male Mice
}

\author{
Beom-Jun LEE'), Eun-Yong JUNG ${ }^{1)}$, Young-Won YUN'1), Jong-Koo KANG ${ }^{1}$, \\ In-Jeoung BAEK ${ }^{1)}$, Jung-Min YON ${ }^{1}$, , Yoon-Bok LEE ${ }^{1)}$, Heon-Soo SOHN ${ }^{2}$, \\ Jae-Yong $\mathrm{LEE}^{3)}$, Kang-Sung $\mathrm{KIM}^{4)}$ and Sang-Yoon NAM ${ }^{1)}$ \\ 1)Department of Veterinary Medicine and Research Institute of Veterinary Medicine, \\ Chungbuk National University, Cheongju 361-763, ${ }^{2)}$ Central Research Institute, Dr. Chung's \\ Food Co., Ltd., Cheongju 360-290, 3)Department of Biochemistry, College of Medicine, \\ Hallym University, Chunchon 200-702, ${ }^{4)}$ Department of Food Science and Nutrition, Yong-In \\ University, Yongin 449-714, Korea
}

\begin{abstract}
Genistein, a soybean-originated isoflavone, is widely consumed by humans for putative beneficial health effects but its estrogenic activity may affect adversely the development of the male reproductive system. Twenty-one days old ICR mice weaned from dams fed with a casein-based AIN-76A diet during gestation and lactation were exposed to genistein ( 2.5 and $5.0 \mathrm{mg} / \mathrm{kg} /$ day, p.o.) for 5 weeks. $17 \beta$-Estradiol $(7.5 \mu \mathrm{g} / \mathrm{kg} /$ day) and corn oil were used for the positive and negative vehicle controls, respectively. The animals were fed the casein-based AIN-76A diet throughout the experiment. There were no significant differences in body weights of mice between the genistein groups and the negative control group. No significant differences in relative reproductive organ weights were found among all experimental groups. Sperm counts in epididymis and testes were slightly decreased in the genistein-exposed groups compared with control group. Sperm motile characteristics in genistein-exposed groups were slightly higher than those of the control group. Levels of phospholipid hydroxide glutathione peroxidase mRNA in the testis, epididymis, and prostate of mice exposed to genistein or estradiol were significantly higher than those of the controls $(\mathrm{P}<0.05)$. Exposure to genistein caused hyperplasia of Leydig cells in the testis and a slight increase of interstitial fibroblasts in the epididymis, while estradiol treatment caused severe damage to the testis and epididymis. These results suggest that dietary uptake of genistein during the juvenile period may affect male reproductive development, resulting in a slight decrease in sperm count, but with an increase in sperm motion quality.

Key words: Estradiol, Genistein, Phospholipid hydroxide glutathione peroxidase, Reproductive toxicity, Sperm
\end{abstract}

(J. Reprod. Dev. 50: 399-409, 2004)

G enistein (4',5,7-trihydroxy-isoflavone), the principal soybean isoflavone, has been the subject of numerous studies in experimental animals and humans because of its possible beneficial health effects and adverse effects due to

Accepted for publication: March 19, 2004

Correspondence: S-Y. Nam (e-mail: synam@cbu.ac.kr) estrogenic activity [1]. Epidemiological studies have revealed that individuals who consume a traditional diet high in soybean products have a low incidence of certain types of cancer, such as breast, prostate and colon cancer [2]. Diets high in soybean contain multiple agents that may contribute to these effects. Nonetheless, much 
research attention has focused on the isoflavones and particularly genistein, as active compounds responsible for the beneficial effects of soybean [3]. In the typical eastern Asian diet, $1.5 \mathrm{mg} / \mathrm{kg} /$ day of genistein or other isoflavones may be ingested, whereas the typical western European diet contains less than $0.2 \mathrm{mg} / \mathrm{kg} /$ day [4]. The health benefits of soybean isoflavones may be due to the presence of estrogenicity and/or anti-estrogenicity and other biological activities such as inhibition of angiogenesis, cell proliferation, tyrosine kinase activity, free radical production and steroid metabolizing enzymes [5-7].

Research assessing the potential adverse effects associated with isoflavone consumption is primarily directed toward defining any potential risk from exposure to a range of doses of isoflavones during different life stages. There has been considerable debate over the possible risk and/or benefits of isoflavone consumption during the sensitive stages of fetal and infant development, because of the weak estrogenic activity of genistein and other isoflavones $[8,9]$. Early developmental exposure to estrogenic chemicals is known to cause reproductive tract abnormalities, decreases in reproductive organ weights, and to potentially compromise sperm production and sperm quality in experimental animals, wildlife and humans [1012]. These findings have raised concern over exposure to estrogenic isoflavonoids and other exogenous weak estrogens in our food and water supplies. Because of the widespread exposure of humans to significant doses of soybean isoflavones at various stages of development, the data obtained from animal models can be evaluated for its relevance to human risk assessment more readily than is the case for the other endocrine active chemicals with limited human exposure.

Recently, many researchers reported the effects of genistein on the reproductive functions [13-16]. Several papers showed no adverse effects of genistein on mammarian reproductive systems at the human intake dose level [14, 15, 17, 18]. Meanwhile, some showed adverse effects of genistein on reproductive function after puberty in animals $[13,16,19]$. The discrepancy in those results may be due to differences in time, duration and dose of exposure to genistein and/or use of animal species and strains.

In the present study, we chose two exposure doses of 2.5 and $5 \mathrm{mg} / \mathrm{kg} /$ day genistein which broadly cover the average exposure level $(4 \mathrm{mg} / \mathrm{kg}$ genistein) of infants to total isoflavones in soy milk as well as the typical Asian diet level of $1.5 \mathrm{mg} / \mathrm{kg}$ / day genistein. The objective of the present study was to evaluate whether genistein causes adverse effects on the reproductive system of male mice when exposed to genistein for 5 weeks from postnatal day (PND) 21 to 56 after weaning from dams fed with the casein-based AIN-76A diet during gestation and lactation. Changes in the weight and histopathology of reproductive organs, sperm count and sperm motility, and levels of phospholipid hydroxide glutathione peroxidase (PHGPx) mRNA expression were investigated.

\section{Materials and Methods}

\section{Chemicals}

Genistein (purity, >98\%), 17- $\beta$ estradiol (E2), and corn oil were obtained from Sigma Chemical Co. (St. Louis, MO, U.S.A.). Genistein was diluted with corn oil and mixed vigorously prior to use. The other chemicals and reagents used in this study were also purchased from Sigma and were of the highest grade commercially available.

\section{Laboratory animals}

ICR mice were purchased from Biolink Inc. (Seoul, Korea) and housed in polycarbonate cages with wood chip bedding. The animal facilities were maintained under controlled conditions with temperature of $21 \pm 2 \mathrm{C}$, relative humidity of $50 \pm$ $10 \%$, and artificial illumination with a 12-h lightdark cycle. All animals received humane care as outline by the "Guide for the care and use of animals" (Chungbuk National University Animal Care Committee according to NIH \#86-23). Animals were fed with the casein-based AIN-76A diet (Harlan Teklad, Madison, WI, U.S.A.) throughout all experiment periods including mating, pregnancy and weaning periods. Threeweek-old male mice (PND 21) after weaning from dams fed with the casein-based AIN-76A diet were randomly divided into 4 experimental groups (10 mice per group) comprising genistein (2.5 and 5.0 $\mathrm{mg} / \mathrm{kg}), \mathrm{E} 2(7.5 \mu \mathrm{g} / \mathrm{kg})$, and corn oil (vehicle control). The animals were orally administered, daily, with the test compounds for 5 weeks under the casein-based AIN-76A diet. Animals were sacrificed under ethyl ether anesthesia, and their 
reproductive organs including testes, epididymis and prostate were removed and weighed.

\section{Sperm counts in testis and cauda epididymis}

Testicular parenchyma tissue was displaced in 12 $\mathrm{ml}$ distilled water at 4-6 C. The tissue was homogenized at a low speed for 1.5-2 min using a polytron homogenizer (Omni 5000 International Co, Waterburg, CT, U.S.A.) and sonicated for $3 \mathrm{~min}$ at 4 C. Cauda epididymis was chopped with sharp scissors and homogenized at a low speed in $10 \mathrm{ml}$ distilled water for 1.5-2 min at 4-6 C. The number of homogenization-resistant spermatids was enumerated using a hemocytometer.

\section{Analysis of sperm kinematics}

The working medium for mouse sperm kinematics was a modified Tyrode's solution [20], as described by Holloway et al. [21]. It was equilibrated overnight to a $\mathrm{pH}$ of $7.35 \pm 0.5$ in a $5 \%$ $\mathrm{CO}_{2}$ incubator at $37 \mathrm{C}$. For sperm motility assessment, the medium was modified with the addition of $0.4 \%$ bovine serum albumin (BSA) and equilibrated to a $\mathrm{pH}$ of $7.35 \pm 0.5$. Each testis and ex-current duct was immediately recovered by a midline incision. Caudal epididymis and vas deferens were dispersed, dissected free of the epididymis and surrounding fat, and washed in media. The epididymis was placed in $3 \mathrm{ml}$ of the modified Tyrode's medium supplemented with $0.4 \% \mathrm{BSA}$ in a $35 \mathrm{~mm}$ plastic Petri dish at $37 \mathrm{C}$. After the tissue was removed, the sperm suspension was collected, gently mixed, and kept at $37 \mathrm{C}$ in a $5 \% \mathrm{CO}_{2}$ atmosphere. Aliquots of the sperm suspension were diluted with fresh medium to an adequate concentration. The aliquots of $30 \mu \mathrm{l}$ were placed in pre-warmed slide chambers with a depth of $20 \mu \mathrm{m}$. The slide chambers were transferred to the heated plate of an inverted phasecontrast microscope (Olympus IX 70, Tokyo, Japan). PH2 condenser and 4X PH1 object lenses were used to produce pseudo-dark-field views. Computer-assisted sperm motility analysis (CASA) was performed using a sperm image analysis system (SIAS, Medical supply Co. Seoul, Korea). Images were recorded in real-time over extended periods. For each slide, the tracks of sperm in 10 fields were recorded for approximately $2-3 \mathrm{~min}$ [22]. Centroids were used for estimation of the motion endpoint, which includes motility (number of sperm exceeding threshold minimum velocity/ total number of sperm), curvilinear velocity (VCL: mean frame-to-frame velocity), straight-line velocity (VSL: velocity between centroids in first and last frame tracked), average path velocity (VAP: velocity obtained from smoothing the original path), hyper-activated sperm (HYP), beat cross frequency (BCF: frequency of centroids crossing the average trajectory), mean angular displacement (MAD: time-average of absolute values of the instantaneous turning angle of the sperm head along its curvilinear trajectory), lateral head displacement (ALH: displacement of the centroid from a computer-calculated average trajectory). Linearity (LIN: [VSL/VCL] × 100), straightness (STR: [VSL/VAP] $\times 100)$, and dance (DNC: VCL $\times$ ALH) were calculated with the above parameters. These parameters have been modeled and refined mathematically to describe the motion of each spermatozoon as it travels through a microscopic dark field [23].

\section{Histopathological evaluation}

Body weights (every week) and sex organ weights including testis, epididymis and prostate were measured. Testis, epididymis and prostate were fixed in Bouin's fixative and washed with saturated lithium carbonate in $70 \%$ ethyl alcohol to remove excess of the fixative. After normal tissue processing using an automatic tissue processor (Shandon Hypercenter XP, Houston, TX, U.S.A.) and an embedding center (Leica, Solms, Germany), the organ tissues were stained with hematoxylin and eosin (H\&E) and examined microscopically.

\section{Total RNA isolation and reverse transcription-} polymerase chain reaction ( $R T-P C R$ )

As previously reported [24], total RNA was extracted from testis, epididymis, and prostate using the TRIzol ${ }^{\circledR}$ reagent (Life Technologies, Gaithersburg, MD, U.S.A.), according to the manufacturer's instruction. The RNA pellet obtained in the final step was dissolved in $50 \mu \mathrm{l}$ of sterile diethylpyrocarbonate (DEPC)-treated water and its concentration was determined by a UV spectrophotometer at $260 \mathrm{~nm}$. RNA was kept in DEPC-treated water at $-70 \mathrm{C}$ until use. Reverse transcription of mRNA and amplification of cDNA were performed using a Pelter thermal cycler (MJ Research Inc. Waltham, MA, U.S.A.). Total RNA $(1.0 \mu \mathrm{g})$ was synthesized by using the 1st strand cDNA synthesis kit (Boehringer Mannheim, 
Mannheim, Germany) following the manufacturer's instruction. The PCR mixture was as follows: $0.15 \mu \mathrm{l}$ of TaqGold DNA polymerase (Perkin Elmer; Boston, MA, U.S.A.), $1.0 \mu \mathrm{l}$ of sense primer for PHGPx (5'-ATGCA CGAAT TCTCA GCCAA G-3'), $1 \mu$ of antisense primer (5'-GGCAG GTCCT TCTCT AT-3'), $2.5 \mu$ of dNTPs, $2.5 \mu \mathrm{l}$ of 10strength PCR buffer containing $1.5 \mathrm{mM} \mathrm{MgCl}_{2}$, and $1 \mu \mathrm{l}$ of template cDNA in $16.85 \mu \mathrm{l}$ of ultra-distilled water. PCR amplification was carried out in the thermal cycler using a protocol of an initial denaturing step at $95 \mathrm{C}$ for $10 \mathrm{~min}$; then 35 cycles at $95 \mathrm{C}$ for $1 \mathrm{~min}$ (denaturing), at $55 \mathrm{C}$ for $1 \mathrm{~min}$ (annealing), and at $72 \mathrm{C}$ for $1.5 \mathrm{~min}$ (extension), followed by a further extension at $72 \mathrm{C}$ for $10 \mathrm{~min}$. The PCR products were run on a $2 \%$ agarose gel in Tris-borate-EDTA buffer. Each sample was also tested for RNA integrity using GAPDH (intrinsic control) primers: sense primer (5'-AACGG ATTTG GTCGT ATTGG-3'), antisense primer (5'-AGCCT TCTCC ATGGT GGTGA AGAC-3'). The expected PCR products sizes of PHGPx and GAPDH were 462 and $302 \mathrm{bp}$, respectively. The relative absorbance of specific mRNA was normalized to the relative absorbance of GAPDH mRNA.

\section{Statistical analysis}

Data were analyzed using SAS program for ANOVA. The significance of difference between the mean of each treatment group and that of the control group was evaluated statistically by least significant difference (LSD) at the level of $\mathrm{P}<0.05$ and $\mathrm{P}<0.01$.

\section{Results}

\section{Body and organ weights}

Changes in body weights are shown in Fig. 1. There were no significant differences in body weight between vehicle control and genisteinexposed groups. However, E2 treatment significantly decreased the body weight of mice at 3 to 5 weeks after beginning the experiment compared to control $(\mathrm{P}<0.05)$. Relative organ weights for each group are shown in Fig. 2. There were no significant differences in the relative weights of epididymis, testis and prostate between control and genistein-treated groups. However, estradiol treatment caused a significant decrease in the relative weight of the epididymis $(\mathrm{P}<0.05)$.

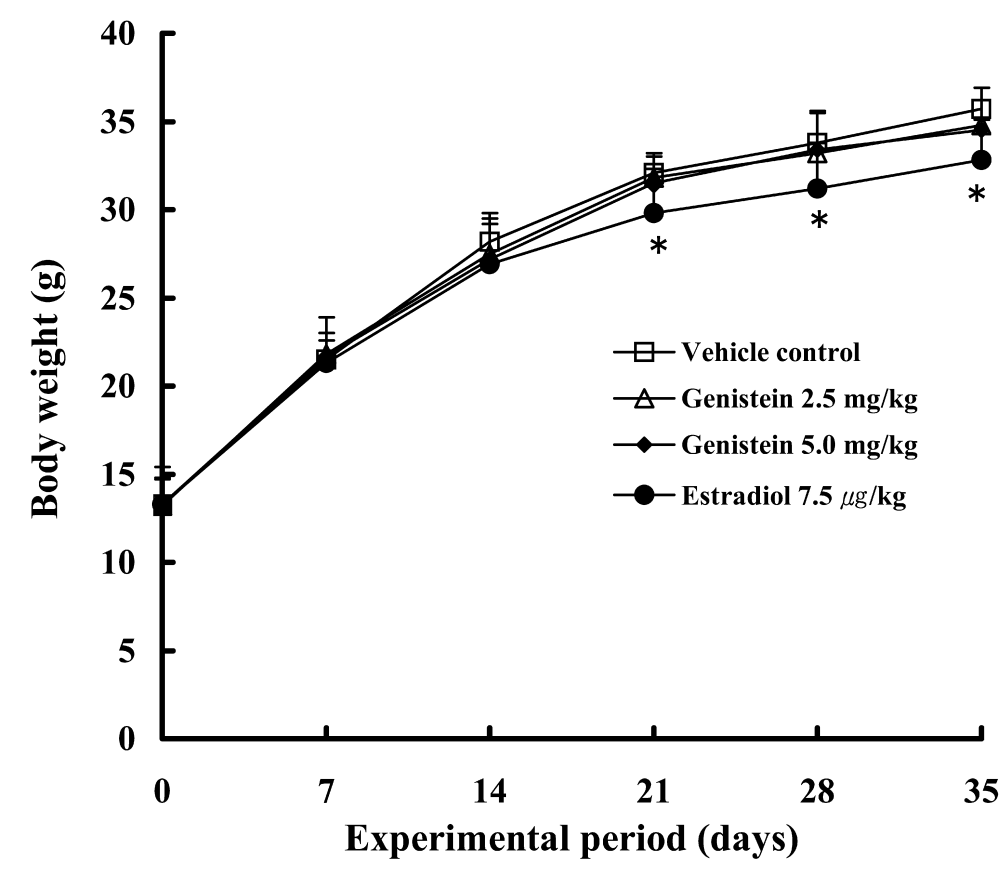

Fig. 1. Average body weight changes in male ICR mice exposed to genistein and $17 \beta$-estradiol for 5 weeks from PND 21 to 56 . Values represent mean $\pm \mathrm{SD}(\mathrm{n}=10)$. ${ }^{*} \mathrm{P}<0.05$, compared to the control. 


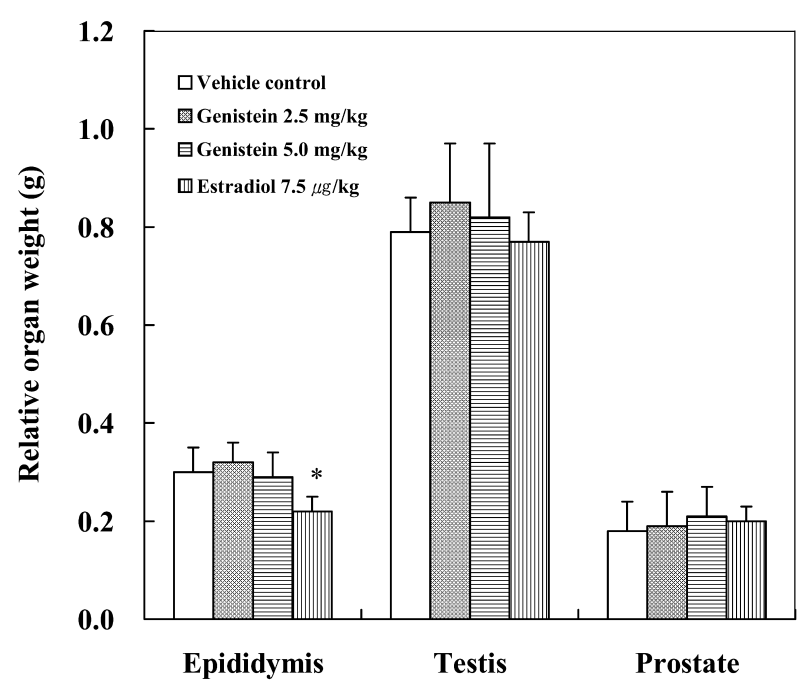

Fig. 2. Relative organ weights in male ICR mice exposed to genistein and $17 \beta$-estradiol for 5 weeks from PND 21 to 56. Values represent mean $\pm \mathrm{SD}(\mathrm{n}=10) .{ }^{*} \mathrm{P}<0.05$, compared to the control.

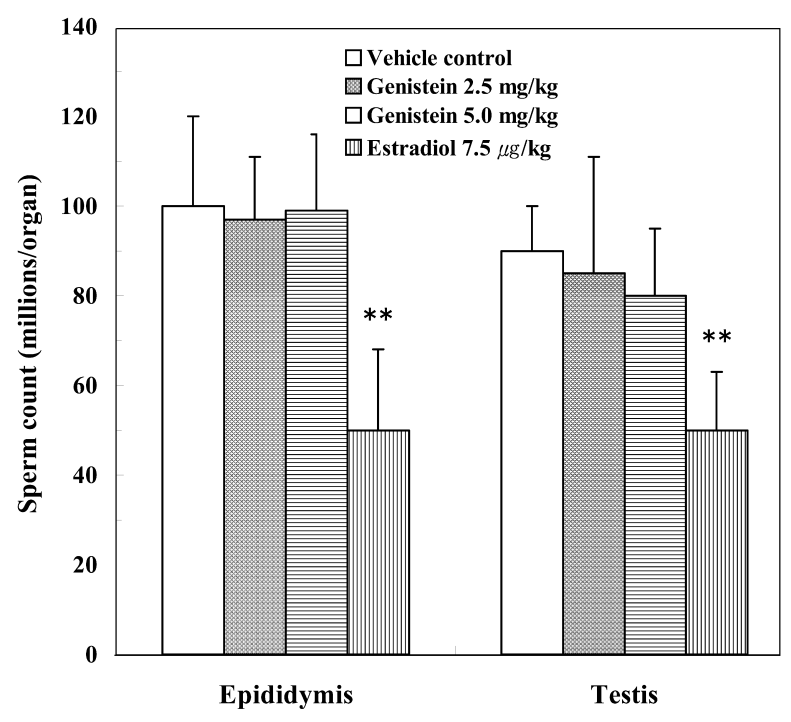

Fig. 3. Epididymal and testicular sperm counts in male ICR mice exposed to genistein and $17 \beta$-estradiol for 5 weeks from PND 21 to 56 . Sperm counts are indicated as millions/one epididymis or testis. Values represent mean $\pm \mathrm{SD}(\mathrm{n}=10) .{ }^{*} \mathrm{P}<0.05$, compared to the control.

\section{Sperm count and sperm motility}

Genistein treatment for 5 weeks through pubertal development slightly decreased sperm counts in the epididymis and testis but they were not significantly different from the control (Fig. 3). E2
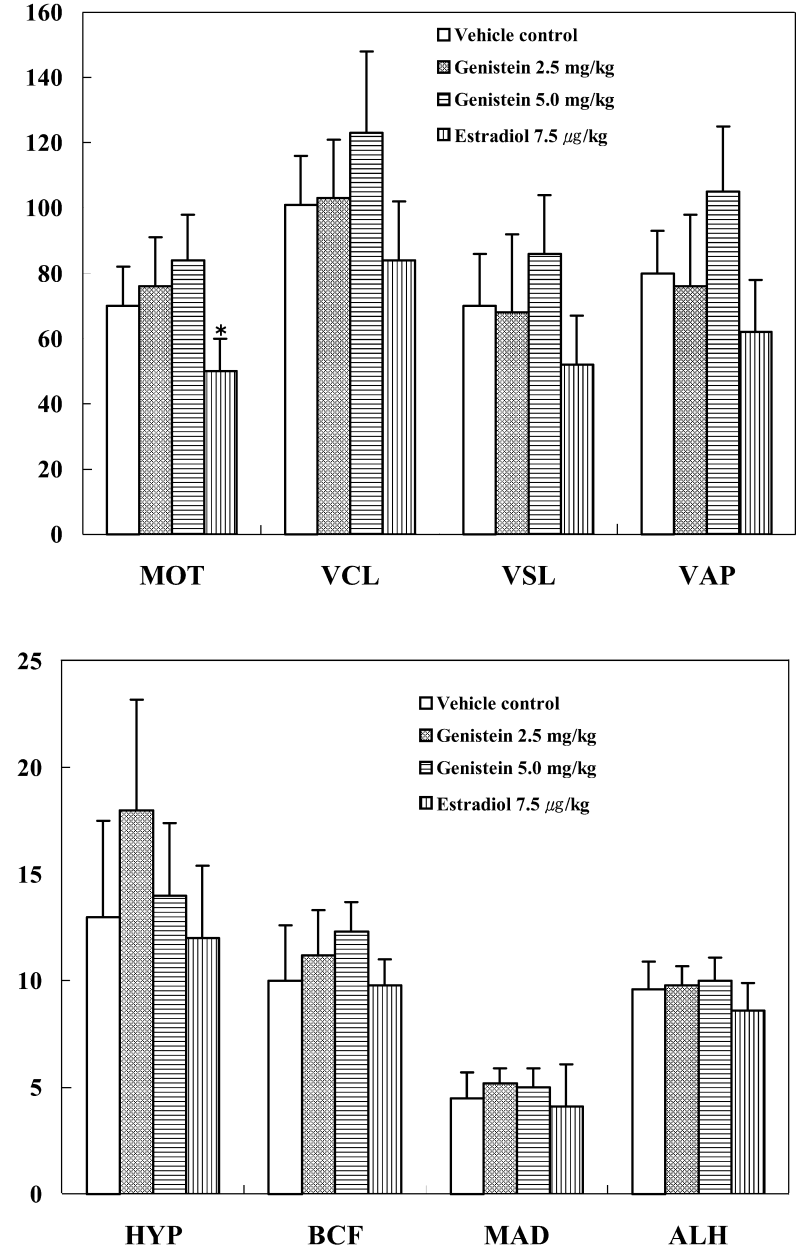

Fig. 4. Sperm motion characteristics in male ICR mice exposed to genistein and estradiol for 5 weeks from PND 21 to 56. Motility: MOT (\%), Curvilinear Velocity: VCL $(\mu \mathrm{m} / \mathrm{s})$, Straight-Line Velocity: VSL $(\mu \mathrm{m} / \mathrm{s})$, Average-Path Velocity: VAP $(\mu \mathrm{m} / \mathrm{s})$, Hyperactivated Sperm: HYP (\%), Beat-Cross Frequency: BCF (Hz), Mean Angular Displacement: MAD (degree), Amplitude of Lateral Head Displacement: ALH $(\mu \mathrm{m})$. Values represent mean \pm $\mathrm{SD}(\mathrm{n}=10) .{ }^{*} \mathrm{P}<0.05$, compared to the control.

treatment caused a significant decrease in sperm counts in both the epididymis and testis, 52.1 and $40.1 \%$, respectively, compared to control $(\mathrm{P}<0.01)$. Changes in sperm motile characteristics induced by genistein exposure are shown in Fig. 4. Genistein exposure at the dose of $2.5 \mathrm{mg} / \mathrm{kg}$ increased sperm quality as determined by several parameters including MOT, VCL, BCF, MAD and ALH, but they were not significantly different from the control (Fig. 4). At the dose of $5.0 \mathrm{mg} / \mathrm{kg}$, genistein 
exposure also enhanced sperm quality of all the parameters compared to control (Fig. 4). E2 treatment suppressed all sperm quality parameters, and especially it significantly decreased sperm motility compared to control $(\mathrm{P}<0.05)$.

\section{PHGPx mRNA expression}

Genistein exposure during pubertal development increased the expression levels of PHGPX mRNA in testis, epididymis and prostate in a dose-dependent manner (Fig. 5). There were significant differences in the expression of PHGPx mRNA of the testis $(\mathrm{P}<0.05)$, epididymis $(\mathrm{P}<0.01)$, and prostate $(\mathrm{P}<0.01)$ between the high dose group of genistein and the control group (Fig. 5). E2 treatment caused a significant enhancement of the PHGPx mRNA expression in testis, epididymis and prostate compared to the control $(\mathrm{P}<0.01)$.

\section{Histopathological findings}

Exposure to genistein caused hyperplasia of Leydig cells in the testes of mice, while E2 treatment caused inadequate preservation of seminiferous tubules in the subcapsular area with cytoplasmic rarefaction and separation of spermatogenic cells in the seminiferous epithelium (Fig. 6). In the epididymis (Fig. 7), genistein exposure caused an increase of interstitial fibroblasts and a slightly irregular arrangement of the epithelium (Fig. 7A and B). Depletion of the epithelium and the appearance of abnormal spermatogenic cells in epididymal ducts were also observed in the epididymis of mice treated with E2 (Fig. 7D). In the prostate (Fig. 8), E2 treatment caused hyperplasia of epithelial cells (Fig. 8C).

\section{Discussion}

An early exposure to exogenous estrogenic chemicals can disrupt male reproductive development and impair fertility at later stages of life [10-12]. Many rodent diets contain compounds such as soybean isoflavones known to have estrogenic properties [25]. The dietary background of phytoestrogens may modulate some responses to environmental estrogens when these compounds are tested in a rodent bioassay [26]. Therefore, we used a casein-based open formula (AIN-76A) purified diet with non-detectable levels of estrogenic isoflavones, genistein, diadzein or
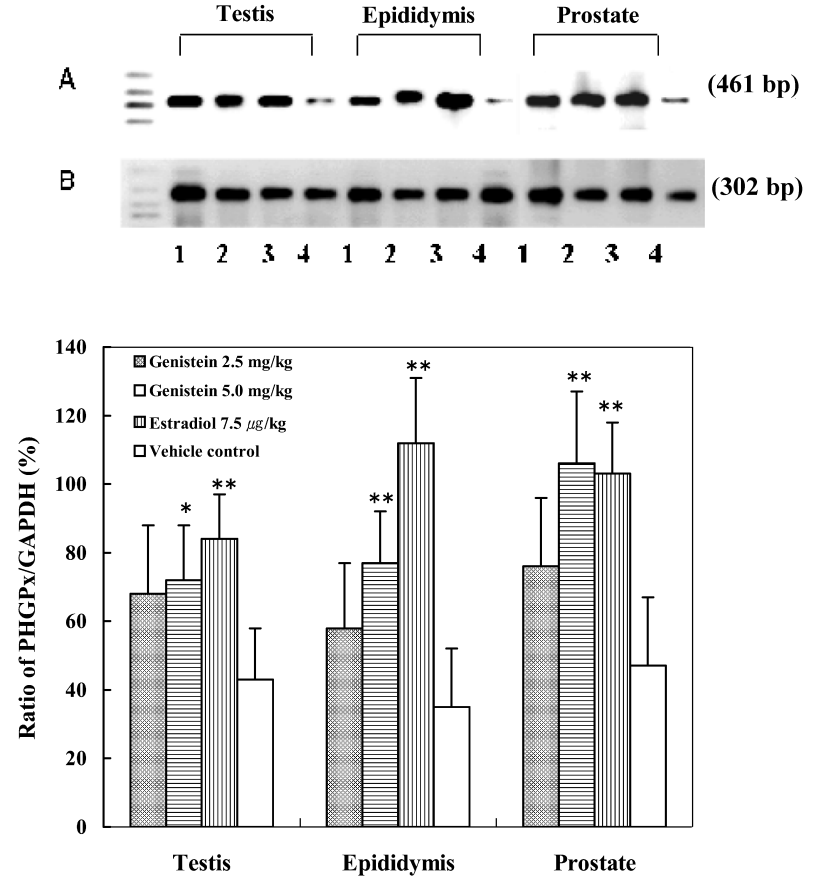

Fig. 5. PHGPx mRNA expression patterns in male ICR mice exposed to genistein and estradiol for 5 weeks from PND 21 to 56 . Genistein $2.5 \mathrm{mg} / \mathrm{kg} /$ day (1), Genistein $5.0 \mathrm{mg} / \mathrm{kg} /$ day (2), $17 \beta$-estradiol $7.5 \mu \mathrm{g} /$ $\mathrm{kg} /$ day (3), Vehicle control (4). cDNAs of testis, epididymis and prostate loaded on $2.0 \%$ agrose gel. A) A representative expression of PHGPx mRNA and B) the corresponding GAPDH mRNA. The ratios of PHGPx and GAPDH bands were calculated.

glycitein [27]. The present study clearly showed that exposure to genistein by oral gavage during pubertal development did not significantly affect male reproductive functions including sperm counts and sperm quality. Although the exposure to genistein caused a slight change in histopathology of testis and epididymis, there were no significant effects on weights of body and reproductive organs including the testis, epididymis and prostate. However, treatment of E2, as an endogenous positive control, caused severe impairment of the reproductive system of mice, especially a decrease in sperm count and sperm motility.

The effects of genistein on reproductive development in animals are still controversial. Several reports showed that maternal exposure to genistein at a dose comparable to human intake during gestation and/or lactation has no adverse effects on numbers of live pups and implantation 

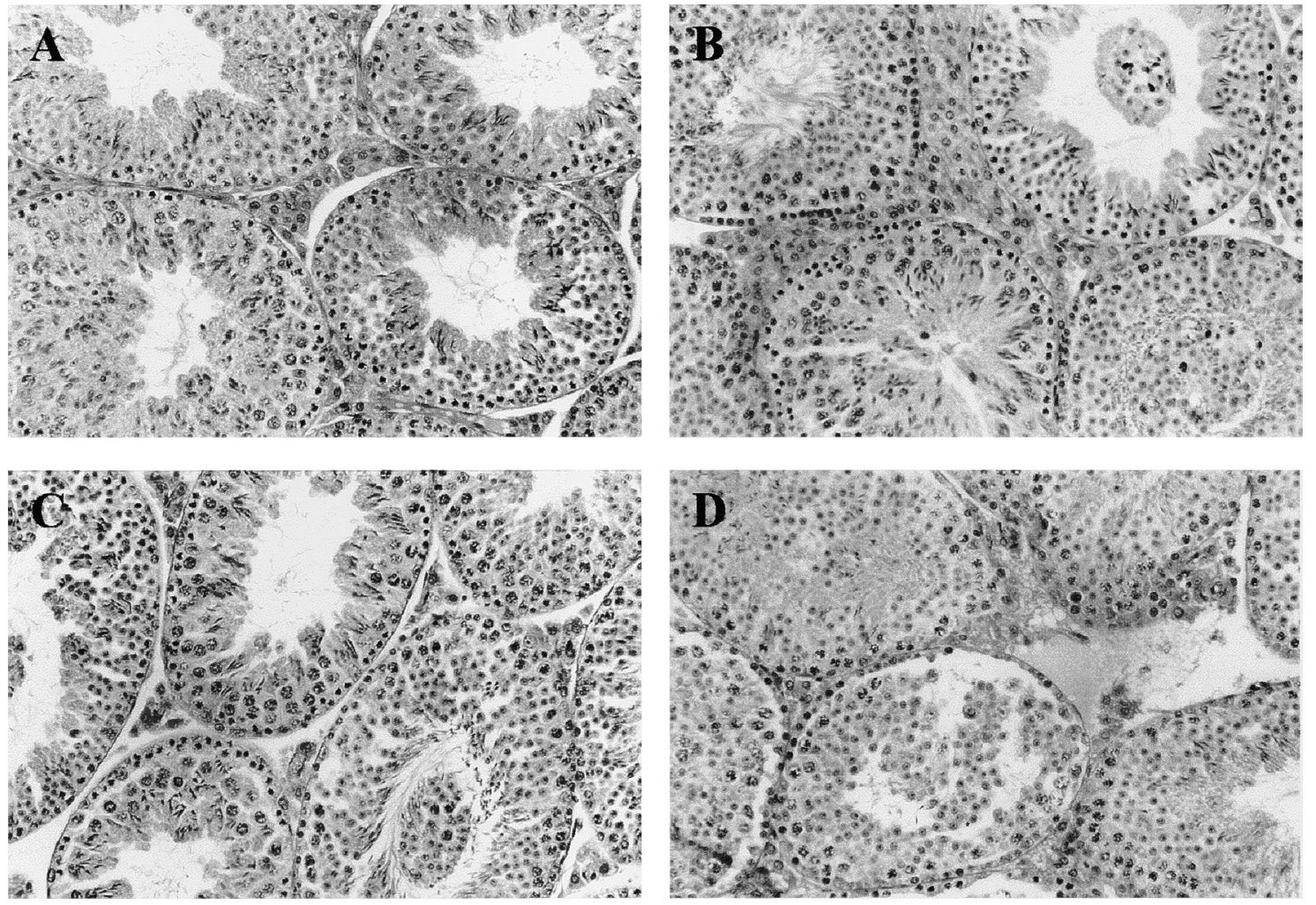

Fig. 6. Histopathology of testes in male ICR mice exposed to genistein and $17 \beta$-estradiol for 5 weeks from PND 21 to 56. (A): Vehicle control, (B): Genistein (2.5 mg/kg/day)—Hyperplasia of Leydig cell, (C): Genistein (5 mg/ $\mathrm{kg} /$ day)-Hyperplasia of Leydig cell, (D): $17 \beta$-estradiol (7.5 $\mu \mathrm{g} / \mathrm{kg} /$ day)-Inadequate preservation of seminiferous tubules in subcapsular area with cytoplasmic rarefaction and separation of spermatogenic cells from the epithelium. $\mathrm{H} \& \mathrm{E}, \times 100$.

sites, sex ratio, anogenital distance, eyelid/vaginal opening and body weight of live pups as well as reproductive organs weight and gametogenic function in F1 male offspring [14, 15, 28]. Lewis et al. [17] reported that neonatal exposure to genistein at $40 \mathrm{mg} / \mathrm{kg} /$ day during birth and PND 21 affected development of female reproductive organs, but not development of male reproductive organs in offspring [17]. Fritz et al. [18] also reported that dietary exposure to genistein (250 and $1000 \mathrm{ppm})$ from PND 21 to 35 did not adversely affect testicular development, but dietary exposure to diethylstibesterol (75 $\mu \mathrm{g} / \mathrm{kg}$ in diet) severely affected testicular development in rats. Although there were differences in timing, duration and dose of exposure to genistein, and use of animal species and strains, these reports clearly showed no adverse effects of genistein in animals. Our results are consistent with theirs in that body weight, organ weight and sperm counts were not affected by exposure to genistein during pubertal development.

Adverse effects of genistein on reproductive system have also been reported. Nagao et al. [16] reported that oral exposure to genistein at doses of $12.5,25,50$ and $100 \mathrm{mg} / \mathrm{kg}$ on PND 1 through 5 after puberty decreased body weights in female and male rats. Estrous cycle and fertility in female rats were also affected by the genistein treatment at the dose of $100 \mathrm{mg} / \mathrm{kg} /$ day [16]. Delclos et al. [13] reported that dietary exposure of genstein at 1,250 ppm to pregnant and lactating dams starting on gestation day-7 affected function and histology of reproductive organs in both female and male pups. Wisniewski et al. [19] also reported that perinatal exposure to genistein results in transient and lasting alterations in masculinization of the reproductive system in male rats. Strauss et al. [29] reported that in adult male mice, genistein induced typical estrogenic effects in doses comparable to 

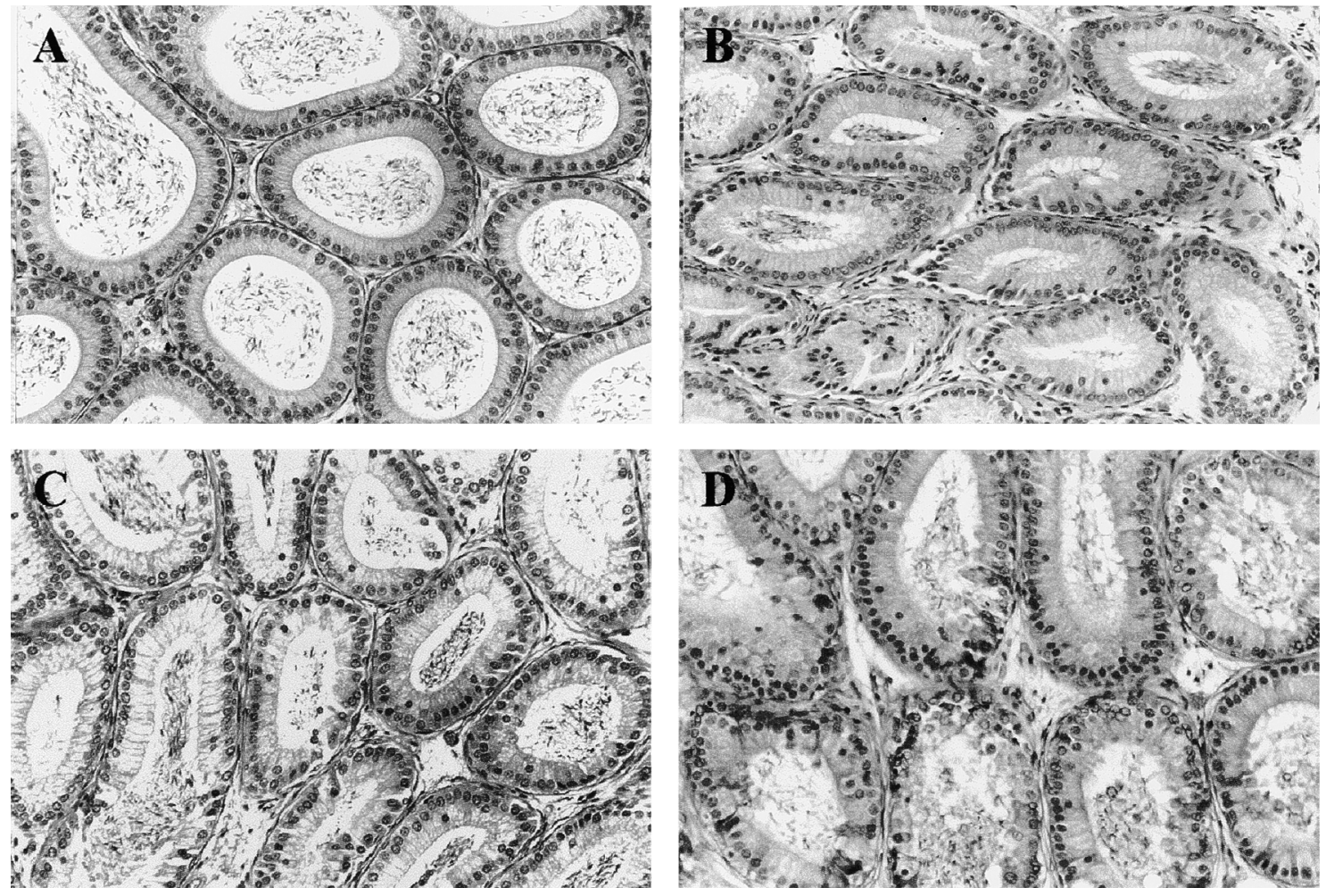

Fig. 7. Histopathology of epididymis in male ICR mice exposed to genistein and $17 \beta$-estradiol for 5 weeks from PND 21 to PND 56. (A): Vehicle control, (B): Genistein $(2.5 \mathrm{mg} / \mathrm{kg} /$ day) —an increase in interstitial fibroblasts, (C): Genistein ( $5 \mathrm{mg} / \mathrm{kg} /$ day)—slightly irregular arrangement of the epithelium, (D): $17 \beta$ estradiol $(7.5 \mu \mathrm{g} / \mathrm{kg} /$ day —depletion and destruction of the epithelium. $\mathrm{H} \& \mathrm{E}, \times 100$.

those present in soybean-based diets, while in neonatal animals, considerably higher doses were required to show estrogen-like activity. These adverse effects may be due to the ability of genistein to cross placenta and reach the fetal brain at maternal serum genistein levels that are comparable to those observed in humans [30]. These reports suggest that dietary genistein ranges available in humans produce effects in multiple estrogen-sensitive tissues in males and females that are generally consistent with its estrogenic activity [13]. In the present study, exposure to genistein induced slight histopathological changes in the testis and epididymis of mice. These changes may be related to weak estrogenic activity of genistein, because E2 treatment induced severe impairment of the male reproductive system [24]. In addition, estrogenic compounds are known to increase PHGPx expression in the testis and prostate of rats, probably due to protection against, or compensation for, damage by the compounds [24]. Our study showed that genistein or E2 exposure significantly increased PHGPx expression in the testis, epididymis, and prostate. The increase of PHGPx induced by genistein in the male reproductive organs may be compensating for the estrogenic activity.

Sperm motility is an important factor for maintaining fertilization. Genistein inhibits the induction of acrosomal exocytosis and binding of spermatozoa to the zona pellucida (ZP) [31]. ZPinduced acrosomal exocytosis in cat spermatozoa is regulated via a tyrosine kinase-dependent pathway, suggesting that a defect in the signaling pathway may cause a compromised sperm dysfunction [32]. Genistein, an inhibitor of protein phosphorylation and dephosphorylation, may play regulatory roles in mediating mouse sperm capacitation [33]. A previous in vivo report showed that genistein inhibited tyrosine phosphorylation of sperm tail protein and blocks capacitation and subsequent sperm hyperactivity [34]. The in vivo effect may be associated with a decrease in the fertilizing ability of sperm. However, many reports 

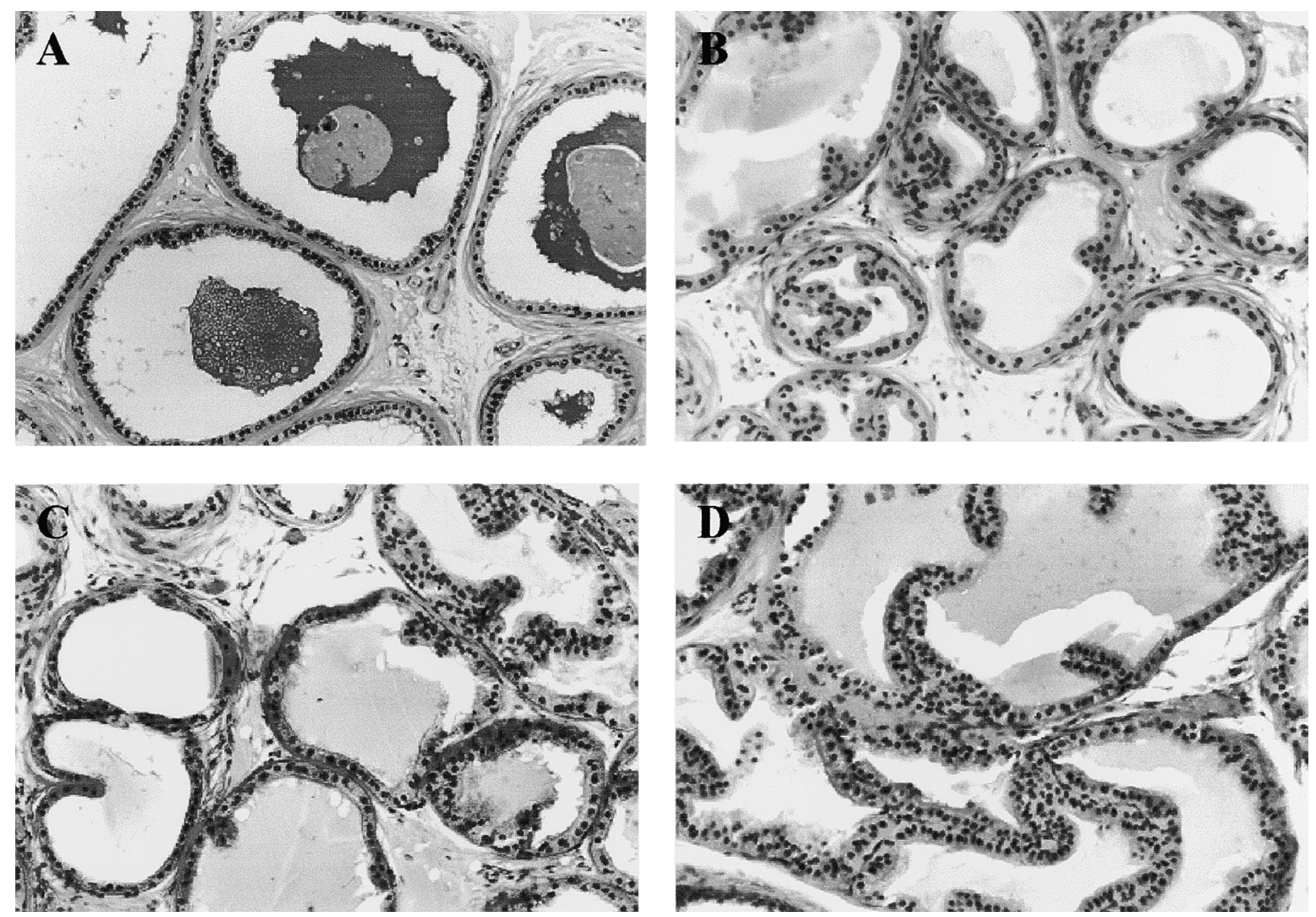

Fig. 8. Histopathology of prostate in male ICR mice exposed to genistein and $17 \beta$-estradiol for 5 weeks from PND 21 to 56. (A): Vehicle control, (B): Genistein ( $2.5 \mathrm{mg} / \mathrm{kg} /$ day), (C): Genistein ( $5 \mathrm{mg} / \mathrm{kg} /$ day), (D): $17 \beta$-estradiol (7.5 $\mu \mathrm{g} /$ $\mathrm{kg} /$ day)-Hyperplasia of epithelial cells. H \& E, $\times 100$.

have shown that genistein has no effects on sperm motility parameters $[15,16,35]$. In the present study, the oral exposure to genistein slightly increased sperm motility and hyperactivity compared to the control. Fielden $e t$ al. [14] reported that exposure to genistein at a dose of $10 \mathrm{mg} / \mathrm{kg}$ / day significantly increased the in vitro fertilizing ability of epididymal sperm by $17 \%$.

Although several reports indicate adverse effects of genistein on the reproductive system, our results suggest that daily intake of genistein at levels comparable to those found in human diets has no observable detrimental effects on male reproductive development. The present study extends our knowledge of the effects of early genistein exposure on male development and may have implications for human health in terms of potential relationships of endocrine disruptors and urogenital abnormalities thought to be increasing in incidence in boys and men.

\section{Acknowledgements}

This study was supported by a grant from the Korea Health 20 R\&D Project, Ministry of Health and Welfare, Republic of Korea (00-PJ1-PG4-PT040003).

\section{References}

1. Setchell KD. Phytoestrogens: the biochemistry, physiology, and implications for human health of soy isoflavones. Am J Clin Nutr 1998; 68:1333s-1346s. 2. Adlercreutz $\mathbf{H}$. Western diet and Western diseases: 
some hormonal and biochemical mechanisms and associations. Scand J Clin Lab Invest suppl 1990; 50: 323.

3. Chen WF, Huang $\mathrm{MH}$, Tzang $\mathrm{CH}$, Yang $\mathbf{M}$, Wong MS. Inhibitory actions of genistein in human breast cancer (MCF-7) cells. Biochim Biophys Acta 2003; 1638: 187-196.

4. Coward L, Barnes NC, Setchell KDR, Barnes S. Genistein and daidzein, and their-glucoside conjugate: anti-tumor isoflavones in soybean foods from American and Asian diets. J Agric Food Chem 1993; 41: 1961-1967.

5. Bouker KB, Hilakivi-Clarke L. Genistein: does it prevent or promote breast cancer? Environ Health Perspect 2000; 108: 701-708.

6. Whitten PL, Patisaul HB. Cross-species and interassay comparisons of phytoestrogen action. Environ Health Perspect 2001; 109 (Suppl 1): 5-20.

7. Hodek P, Trefil P, Stiborova M. Flavonoids-potent and versatile biologically active compounds interacting with cytochromes P450. Chem Biol Interact 2002; 139: 1-21.

8. Sweeney T. Is exposure to endocrine disrupting compounds during fetal/post-natal development affecting the reproductive potential of farm animals? Domest Anim Endocrinol 2002; 23: 203-209.

9. Lamartiniere CA, Murrill WB, Manzolillo PA, Zhang JX, Barnes S, Zhang X, Wei H, Brown NM. Genistein alters the ontogeny of mammary gland development and protects against chemicallyinduced mammary cancer in rats. Proc Soc Exp Biol Med 1998; 217: 358-364.

10. Colborn T, Vom SF, Soto AM. Developmental effects of endocrine-disrupting chemicals in wildlife and humans. Environ Health Perspect 1993; 101: 378384.

11. David J, Hendelsmen S, Wishart A, Conway J. Oestradiol enhances testosterone-induced suppression of human spermatogenesis. Hum Reprod 2000; 15: 672-679.

12. Spearow JL, Doemeny P, Sera R. Genetic variation susceptibility to endocrine disruption by estrogen in mice. Science 1999; 285: 1259-1261.

13. Delclos KB, Bucci TJ, Lomax LG, Latendresse JR, Warbritton A, Weis CC, Newbold RR. Effects of dietary genistein exposure during development on male and female SD (Sprague-Dawley) rats. Reprod Toxicol 2001; 15: 647-663.

14. Fielden MR, Samy SM, Chou KC, Zacharewski TR. Effect of human dietary exposure levels of genistein during gestation and lactation on longterm reproductive development and sperm quality in mice. Food Chem Toxicol 2003; 41: 447-454.

15. Kang KS, Che JH, Lee YS. Lack of adverse effects in the F1 offspring maternally exposed to genistein at human intake dose level. Food Chem Toxicol 2002; 40: 43-51.
16. Nagao T, Yoshimura $S$, Saito $\mathbf{Y}$, Nakagomi $\mathbf{M}$, Usumi K, Ono H. Reproductive effects in male and female rats of neonatal exposure to genistein. Reprod Toxicol 2001; 15: 399-411.

17. Lewis RW, Brooks N, Milburn GM, Soames A, Stone S, Hall M, Ashby J. The effects of the phytoestrogen genistein on the postnatal development of the rat. Toxicol Sci 2003; 71: 74-83.

18. Fritz WA, Cotroneo MS, Wang J, Eltoum IE, Lamartiniere CA. Dietary diethylstilbestrol but not genistein adversely affects rat testicular development. J Nutr 2003; 133: 2287-2293.

19. Wisniewski AB, Klein SL, Lakshmanan $\mathbf{Y}$, Gearhart JP. Exposure to genistein during gestation and lactation demasculinizes the reproductive system in rats. J Urol 2003; 169: 1582-1586.

20. Toyoda Y, Chang MC. Fertilization of rat eggs in vitro by epididymal spermatozoa and the development of eggs following transfer. J Reprod Fertil 1974; 36: 9-22.

21. Holloway AJ, Moore HDM, Foster PMD. The use of in vitro fertilization to detect reductions in the fertility of male rats exposed to 1,3-dinitrobenzene. Fundam Appl Toxicol 1990; 14: 113-122.

22. Yu WJ, Lee BJ, Nam SY, Kim YC, Lee YS, Yun YW. Spermatogenetic disorders in adult rats exposed to tributyltin chloride during puberty. J Vet Med Sci 2003; 65: 1331-1335.

23. Cancel AM, Lobdell D, Mendola P, Perreault SD. Objective evaluation of hyperactivated motility in rat spermatozoa using computer-assisted sperm analysis. Hum Reprod 2000; 15: 1322-1328.

24. Nam SY, Baek IJ, Lee BJ, In CH, Jung EY, Yon JM, Ahn BW, Kang JK, Yu WJ, Yun YW. Effects of $17 \beta-$ estradiol and tamoxifen on the selenoprotein phospholipids hydroperoxide glutathione peroxidase (PHGPx) mRNA expression in male reproductive organs of rats. J Reprod Dev 2003; 49: 389-396.

25. Degen GH, Janning P, Diel P, Michna H, Bolt HM. Transplacental transfer of the phytoestrogen daidzein in DA/Han rats. Arch Toxicol 2002; 76: 23 29.

26. Stroheker T, Chagnon MC, Pinnert MF, Berges $R$, Canivenc-Lavier MC. Estrogenic effects of food wrap packaging xenoestrogens and flavonoids in female Wistar rats: a comparative study. Reprod Toxicol 2003; 17: 421-432.

27. Thigpen JE, Setchell KD, Ahlmark KB, Locklear J, Spahr T, Caviness GF, Goelz MF, Haseman JK, Newbold RR, Forsythe DB. Phytoestrogen content of purified, open- and closed-formula laboratory animal diets. Lab Anim Sci 1999; 49: 530-536.

28. Roberts D, Veeramachaneni DN, Schlaff WD, Awoniyi CA. Effects of chronic dietary exposure to genistein, a phytoestrogen, during various stages of development on reproductive hormones and 
spermatogenesis in rats. Endocrine 2000; 13: 281-286.

29. Strauss L, Makela S, Joshi S, Huhtaniemi I, Santti R. Genistein exerts estrogen-like effects in male mouse reproductive tract. Mol Cell Endocrinol 1998; 144: 83-93.

30. Doerge DR, Churchwell MI, Chang HC, Newbold RR, Delclos KB. Placental transfer of the soy isoflavone genistein following dietary and gavage administration to Sprague Dawley rats. Reprod Toxicol 2001; 15: 105-110.

31. Yanagimachi R. Mammalian fertilization. In: Knobil E, Neil JD (eds), The Physiology of Reproduction. New York: Raven Press; 1994: 189-317.

32. Pukazhenthi BS, Wildt DE, Ottinger MA, Howard J. Inhibition of domestic cat spermatozoa acrosome reaction and zona pellucida penetration by tyrosine kinase inhibitors. Mol Reprod Dev 1998; 49: 48-57.

33. Furuya S, Endo Y, Oba M, Nozawa S, Suzuki S. Effects of modulators of protein kinases and phosphatases on mouse sperm capacitation. J Assist Reprod Genet 1992; 9: 391-399.

34. Mahony MC, Gwathmey T. Protein tyrosine phosphorylation during hyperactivated motility of cynomolgus monkey (Macaca fascicularis) spermatozoa. Biol Reprod 1999; 60: 1239-1243.

35. Hinsch KD, Aires V, Hagele W, Hinsch E. In vitro tests for essential sperm functions using the phytooestrogen genistein as a test substance. Andrologia 2000; 32: 225-231. 